\title{
Minocycline is cytoprotective in human corneal endothelial cells and induces anti-apoptotic B-cell CLL/lymphoma 2 (Bcl-2) and X-linked inhibitor of apoptosis (XIAP)
}

\author{
Marcus Kernt, C Hirneiss, A S Neubauer, A Kampik
}

Department of Ophthalmology, Ludwig-Maximilians-Universität, Munich, Germany

\section{Correspondence to}

Dr Marcus Kernt, Department of Ophthalmology,

Ludwig-Maximilians-University

Munich, Mathilden St. 8,

Munich 80336, Germany;

marcus.kernt@med.

uni-muenchen.de

Accepted 29 November 2009

\section{ABSTRACT}

Introduction Loss of corneal endothelial cells (CECS) is one major factor limiting transplant clarity and survival after keratoplasty. Amongst other factors, apoptosis due to cellular stress is responsible for these problems. This study investigates the possible anti-apoptotic and cytoprotective effects of minocycline on a human corneal endothelial cell line (HCEC-SV40) cultured under oxidative stress and with transforming growth factor beta (TGF- $\beta$ ).

Methods CECs were treated with 1-150 $\mu \mathrm{M}$ minocycline. Cell viability and the median inhibitory concentration $\left(\mathrm{IC}_{50}\right)$ were evaluated after $48 \mathrm{~h}$ and after $\mathrm{H}_{2} \mathrm{O}_{2}$ treatment (tetrazolium dye reduction assay and live-dead assay). Expression of B-cell CLL/lymphoma 2 (Bcl-2) and X-linked inhibitor of apoptosis (XIAP) and their mRNA were assessed by reverse transcriptase (RT)-PCR and western blot analysis after treatment with minocycline alone and consecutive incubation with $200 \mu \mathrm{M} \mathrm{H} \mathrm{O}_{2}$ and TGF- $\beta 2$. A quantitative detection of histone-associated DNA fragmentation by ELISA was performed.

Results Minocycline concentrations from 1-50 $\mu \mathrm{M}$ showed no toxic effects on CECs. Pre-treatment with 10-40 $\mu \mathrm{M}$ minocycline led to an increase in viability after $\mathrm{H}_{2} \mathrm{O}_{2}$ treatment. In addition, minocycline pretreatment attenuated the increase of histone-associated DNA fragmentation after treatment with $\mathrm{H}_{2} \mathrm{O}_{2}$ and TGF- $\beta 2$ significantly. When CECs were treated with minocycline and then consecutively with $\mathrm{H}_{2} \mathrm{O}_{2}$ or TGF- $\beta 2$, RT-PCR and western blot analysis yielded an overexpression of $\mathrm{Bcl}-2$ and XIAP.

Conclusion In this study minocycline prevented apoptotic cell death in cultured CECs in vitro. Our results suggest that minocycline might offer cytoprotective properties that might help to prevent loss of corneal endothelial cells in vivo.

\section{INTRODUCTION}

Corneal transparency is a major prerequisite for normal vision. The corneal endothelium, which is comprised of a single layer of cells of neural crest origin, maintains the osmotic homeostasis of the cornea and is essential for ensuring corneal clarity. ${ }^{1}$ Therefore, a healthy endothelium is essential. Unlike in other mammalian species, the capacity of the human corneal endothelium for regeneration after injury is severely limited. ${ }^{23}$ In general, wound repair and cell loss are achieved by the enlargement and migration of the surrounding cells. ${ }^{2} 3$ The normal endothelial cell count is about 3000 cells $/ \mathrm{mm}^{2}$ in young adults and decreases to approximately 2000 cells $/ \mathrm{mm}^{2}$ during the lifetime. ${ }^{4}$ Although there is no exact threshold, a cell density less than 400-800 cells $/ \mathrm{mm}^{2}$ often produces corneal opacity through inadequate corneal hydration. ${ }^{1}$ Corneal opacities due to endothelial cell loss are commonly irreversible. In such cases, keratoplasty is often the only therapeutic option to improve vision. ${ }^{5}$

One major quality criterion for donor corneas for transplantation is the endothelial cell count and the success of corneal transplantation depends at least in part on a healthy endothelium in the donor cornea. ${ }^{5}$ It has been demonstrated that the deterioration of the corneal endothelium in donor corneas for transplantation occurs more frequently with increasing length of organ culture time and leads to cell loss. ${ }^{67}$ This results in an increased susceptibility of cells.

Reactive oxygen species (ROS) intermediates and oxidative stress are thought to induce apoptotic cell death and have been implicated in the progression of ageing. ${ }^{8}$ Among various causes, oxidant species and oxidative stress are considered to be cytotoxic, and it has been suggested that they are responsible for corneal cell death. ${ }^{9}$ There is evidence that the loss of endothelial cells is at least partly due to apoptosis. $^{10}$

Apart from this, many models have shown that apoptotic cell death is a result of changes in environmental stimuli, such as growth factors. The transforming growth factor beta (TGF- $\beta$ ) family includes three multifunctional proteins, TGF- $\beta 1$, TGF- $\beta 2$ and TGF- $\beta 3$, that are found in aqueous humour. ${ }^{11}$ TGF- $\beta$ is involved in regulating cell differentiation, cell proliferation and other cell functions. ${ }^{12}$ Altered levels of TGF- $\beta$ have been reported in several ocular conditions and pathologies such as uveitis, glaucoma or diabetes, and are considered to be pro-apoptotic. ${ }^{11}{ }^{13-15}$ In addition, it has been demonstrated that the activity of TGF- $\beta$ is related to the production of hydrogen peroxide $\left(\mathrm{H}_{2} \mathrm{O}_{2}\right)$ and induces oxidative stress in lens epithelial cells. ${ }^{16}$ TGF- $\beta 2$, the isoform of TGF- $\beta$ most strongly expressed in human eyes, reportedly inhibits the proliferation of corneal endothelial cells. ${ }^{17} 18$ Furthermore, TGF- $\beta 2$ stimulates prostaglandin synthesis in corneal endothelium and inhibits its proliferation in a dose-dependent manner. ${ }^{18}$

Minocycline is a semi-synthetic, second-generation tetracycline. It is cheap, widely available and 
has proven its safety and its beneficial antimicrobial and antiinflammatory actions for many years. ${ }^{19}$ In addition, minocycline has recently been demonstrated to have cytoprotective properties in several cellular systems, and in models for neurodegenerative and retinal disease. ${ }^{20-23}$ The present study evaluated whether minocycline at various concentrations has toxic effects on cultivated human corneal endothelial cells (CECs). In addition, we investigated the effects of minocycline on viability, induction of cellular death and apoptosis in CECs. To elucidate the potential protective and anti-apoptotic effects of minocycline, the expression of two anti-apoptotic proteins, B-cell CLL/lymphoma 2 (Bcl-2) and X-linked inhibitor of apoptosis (XIAP) and their mRNA were quantified.

\section{METHODS}

Minocycline was obtained as lyophilised powder (Sigma-Aldrich, St Louis, Missouri, USA) and reconstituted with sterile water to obtain a $1 \mathrm{mM}$ stock solution. This stock solution was then further diluted in a 1:1 mixture of M199/F12 medium (M199/ F12; Biochrom, Cambridge, UK) to obtain the final concentrations of $1,5,7.5,10,15,20,40,50,75,100$ and $150 \mu \mathrm{M}$.

\section{Human corneal endothelial cells}

Immortalised, cultured human CECs from a well established cell line (HCEC-SV40) were provided by Professor J Bednarz (University of Hamburg, Klinikum Eppendorf, Hamburg, Germany). ${ }^{24}$ CECs were grown in a 1:1 mixture of M199/F12 medium (Biochrom, Cambridge, UK) supplemented with 5\% fetal calf serum and without addition of antibiotics.

\section{Cell culture treatment}

For all cell culture experiments, CECs $\left(2 \times 10^{5}\right.$ cells/well $)$ were seeded in $35-\mathrm{mm}$ diameter tissue culture dishes and exposed to minocycline concentrations $(1-150 \mu \mathrm{M})$. For exposure to the various concentrations of minocycline, the CECs were kept for $24 \mathrm{~h}$ in serum-free conditions. After the cells were washed with phosphate buffered saline (PBS), they were incubated for $24 \mathrm{~h}$ with various concentrations of minocycline dissolved in a 1:1 mixture of M199/F12 medium for CECs. Then the serum-free medium containing minocycline was removed by carefully rinsing the cells with serum-free medium three times. After another $24 \mathrm{~h}$ of incubation with serum-free medium, cell viability assay, RNA isolation or protein extraction was performed.

For testing the various concentrations of minocycline under conditions of oxidative stress, the cells were treated for $24 \mathrm{~h}$ with the two tested concentrations of minocycline (15 and $20 \mu \mathrm{M}$ ), and then $200 \mu \mathrm{M} \mathrm{H}_{2} \mathrm{O}_{2}$ was added for $4 \mathrm{~h}$.

In unpublished pilot work in our laboratory several concentrations of $\mathrm{H}_{2} \mathrm{O}_{2}$ and different treatment times were tested. The concentration of $200 \mu \mathrm{M} \mathrm{H}_{2} \mathrm{O}_{2}$ and a 4-h treatment was chosen in order to produce an adequate degree of cell injury in untreated CECs.

The serum-free medium containing $\mathrm{H}_{2} \mathrm{O}_{2}$ and minocycline was then removed by carefully rinsing the cells with serum-free medium three times. After another $24 \mathrm{~h}$ of incubation with serum-free medium, cell viability assay, RNA isolation or protein extraction was performed.

For testing minocycline in the presence of TGF- $\beta 2$, cells were treated for $24 \mathrm{~h}$ with the various concentrations of minocycline $(15$ and $20 \mu \mathrm{M})$ and then $1 \mathrm{ng} / \mathrm{ml}$ TGF- $\beta 2$ was added. After another $24 \mathrm{~h}$ of incubation with minocycline and TGF- $\beta 2$, RNA isolation or protein extraction was performed.

\section{MTT assay}

Tetrazolium dye-reduction assay (MTT; 3-[4,5-dimethylthiazol2-yl]-2,5-diphenyl tetrazolium bromide) was used to determine the cell survival rate. The MTT assay was performed as described in the literature by Mosmann ${ }^{25}$ with some modifications. The medium was removed, cells were washed with PBS, and $2000 \mu \mathrm{l} /$ well MTT solution (1.5 $\mathrm{ml}$ MTT stock, $2 \mathrm{mg} / \mathrm{ml}$ in PBS, plus $28.5 \mathrm{ml}$ Dulbecco's modified Eagle's medium (DMEM)) was added. CECs were incubated at $37^{\circ} \mathrm{C}$ for $1 \mathrm{~h}$. Formazan crystals that formed were dissolved by the addition of dimethylsulfoxide (DMSO; $1000 \mu \mathrm{l} /$ well). Absorption was measured by a scanning multiwell spectrophotometer at $550 \mathrm{~nm}$ (Molecular Probes, Garching, Germany). The results were expressed as the mean percentage of the control viability. Experiments were performed in triplicate and repeated three times. CECs from the same passage, incubated with balanced saline without the addition of other substances, served as the control. For all experiments, stationary cell cultures were used. The MTT test, as performed in our study, is a well established test for assessment of cell viability.

\section{Live-dead cell viability assay}

Confluent CECs were prepared and treated as described above. Cell viability was quantified based on a two-colour fluorescence assay. The nuclei of non-viable cells appear red because of staining by the membrane-impermeable dye propidium iodide (Sigma-Aldrich), whereas the nuclei of all cells were stained with the membrane-permeable dye Hoechst 33342 (Intergen; Purchase, New York, USA). Confluent cultures of CECs growing on coverslips in 35-mm tissue culture dishes were exposed to the various concentrations of minocycline as described for the MTT assay. For the evaluation of cell viability, the cells were washed in PBS and incubated with $2.0 \mu \mathrm{g} / \mathrm{ml}$ propidium iodide and $1.0 \mu \mathrm{g} / \mathrm{ml} \mathrm{Hoechst} 33342$ for $20 \mathrm{~min}$ at $37^{\circ} \mathrm{C}$. Subsequently, the cells were analysed with an epifluorescence microscope (Aristoplan; Leitz, Wetzlar, Germany). The labelled nuclei were then counted in fluorescence photomicrographs, and dead cells were expressed as a percentage of the total nuclei in the field. Data (mean \pm SD) are based on the sampling of six to 10 photomicrographs per condition in three independent experiments performed in duplicate. The percentage of dead cells was scored by counting at least 500 cells in fluorescence photomicrographs of representative fields. CECs of the same passage served as the control.

\section{Detection of apoptosis}

Apoptosis is characterised by membrane blebbing, condensation of cytoplasm and the activation of endogenous endonucleoses. This leads to internucleosomal cleavage of DNA and the generation of mono- and oligonucleosomes, which are tightly complexed with histones. To quantify apoptosis in CECs, quantitative detection of histone-associated DNA fragments in mono- and oligonucleosomes, a marker for apoptosis, was performed by an ELISA. CECs were treated with minocycline and $200 \mu \mathrm{M} \mathrm{H}_{2} \mathrm{O}_{2}$ or TGF- $\beta 2$ as described before. Cells were then collected from culture dishes and subjected to a cell death detection ELISA (Roche Applied Science, Indianapolis, Indiana, USA).

\section{RNA isolation and real-time PCR}

The total RNA for Bcl-2 and XIAP detection was isolated from $35-\mathrm{mm}$ tissue culture dishes by the guanidium thiocyanate-phenol-chloroform extraction method. Quantification of Bcl-2 and XIAP mRNA was performed by reverse transcriptase (RT)-PCR using a LightCycler Instrument (LightCycler System, Roche Diagnostics, Germany) according to previous descriptions. $^{26}$ The levels of $\mathrm{Bcl}-2$ and XIAP mRNA were 
determined as a relative ratio ( $R R$ ), which was calculated by dividing the level of Bcl-2 and XIAP mRNA by the level of the $18 \mathrm{~S}$ rRNA housekeeping gene in the same samples. All experiments were performed at least in triplicate and repeated three times. The primers used for RT-PCR are shown in table 1.

Protein extraction and western blot analysis of Bcl-2 and XIAP CECs grown on 35-mm tissue culture dishes were washed twice with ice-cold PBS, collected, and lysed in RIPA cell lysis buffer. After centrifugation for $30 \mathrm{~min}$ at $19000 \mathrm{~g}$ in a microfuge (5810R; Eppendorf, Hamburg, Germany) in the cold, the supernatant fraction was transferred to fresh tubes and stored at $-70^{\circ} \mathrm{C}$ for future use. The protein content was measured by the bicinchoninic acid (BCA) protein assay (Pierce, Rockford, Illinois, USA). Denatured proteins $(1.2 \mathrm{mg}$ ) were separated under reducing conditions by electrophoresis using a 5\% SDS-polyacrylamide stacking gel and a 12\% SDS-polyacrylamide separating gel, transferred with semi-dry blotting onto a polyvinyl difluoride membrane (Roche Diagnostics), and probed with a mouse anti-Bcl-2-antibody or a mouse anti-XIAP-antibody as described previously. ${ }^{26}$ Chemiluminescence was detected with an imager (LAS-1000; RayTest, Straubenhardt, Germany) and generated light units (LU). The exposure times ranged between 1 and $10 \mathrm{~min}$. All experiments were performed at least in triplicate. Quantification of the chemiluminescence signal by densitometry was performed by using a specific computer software (AIDA; RayTest).

\section{Statistical evaluation and expression of results}

All data were analysed using SPSS 17.0 for Windows (SPSS Inc., Chicago, Illinois, USA). For all statistical tests, $\mathrm{p}<0.05$ was considered significant. Results of the MTT assay are presented as mean $( \pm S D)$ units of absorbance. Ten individual samples per group were measured in triplicate. Results of the RT-PCR are presented as mean $( \pm S D)$ ratios of the investigated mRNA and $18 \mathrm{~S}$ rRNA; all experiments were performed in triplicate and repeated three times. Western blot analysis was performed analogously; CEC culture experiments were performed at least in triplicate. Analysis of variance with Bonferroni correction in post hoc testing was applied to investigate statistical significance of differences. To evaluate the effects of treatment with the various concentrations of minocycline univariate ANOVA modelling was performed, considering the factors TGF- $\beta$ treatment and $\mathrm{H}_{2} \mathrm{O}_{2}$ concentration. Post hoc testing for significant factors applied Bonferroni correction.

\section{RESULTS}

\section{Testing concentrations of minocycline in cultured CECs}

No gross abnormalities could be detected in CECs with phasecontrast microscopy for minocycline concentrations up to $75 \mu \mathrm{M}$ (data not shown). The number of cells, counted in phase-contrast microscopy, correlated well with the results of the MTT test.

When CECs that were pre-treated with 15 or $20 \mu \mathrm{M}$ minocycline were treated with $200 \mu \mathrm{M} \mathrm{H}_{2} \mathrm{O}_{2}$, cells showed only very few signs of toxicity. Control cells treated with $200 \mu \mathrm{M} \mathrm{H}_{2} \mathrm{O}_{2}$

Table 1 Primers used for RT-PCR

\begin{tabular}{llclll}
\hline Target & Length & Position & AT $\left({ }^{\circ} \mathbf{C}\right)$ & $\%$ GC & Sequence \\
\hline Bcl-2 & 19 & $3465-3483$ & 60 & 58 & agaggtcacgggggctaat \\
& 20 & $3505-3524$ & 60 & 50 & ccaggtaacaaaaccccaca \\
XIAP & 25 & $846-870$ & 60 & 36 & ttttgggacatggatatactcagtt \\
& 25 & $910-934$ & 59 & 40 & agcactttactttatcaccttcacc \\
\hline
\end{tabular}

$\mathrm{AT}$, annealing temperature; $\mathrm{GC}$, guanine-cytosine content. that had no minocycline pre-treatment showed pronounced morphological signs of toxicity such as abnormal shape and appearance, cellular lysis and destruction (data not shown).

\section{MTT assay}

Minocycline concentrations between 1 and $50 \mu \mathrm{M}$ showed no significant toxic effects on CECs (24 h exposure). No significant decrease in cellular viability was detected compared with the control. Concentrations of minocycline between $75 \mu \mathrm{M}$ $(p=0.696)$ and $100 \mu \mathrm{M}(\mathrm{p} \leq 0.001)$ led to a dose-dependent reduction of viability. The concentration of minocycline that inhibited viability by $50 \%$ ( $\mathrm{IC}_{50}$ ) was determined from the dose-response curves and for 24-h application was approximately $100 \mu \mathrm{M}( \pm 6.8 \mathrm{CI})$ for CECs. The tested minocycline concentrations of $150 \mu \mathrm{M}$ reduced the number of viable cells to less than $30 \%$ (figure 1 ).

When cells were treated with $200 \mu \mathrm{M} \mathrm{H}_{2} \mathrm{O}_{2}$ only, a significant decrease in viability was detected compared with the untreated control cells $(p \leq 0.001)$. In contrast, cells that were treated with minocycline in concentrations between 10 and $40 \mu \mathrm{M}$ and then subsequently treated with $200 \mu \mathrm{M} \mathrm{H}_{2} \mathrm{O}_{2}$ showed no significant decrease in cell viability compared with cells that were treated with minocycline concentrations between 10 and $40 \mu \mathrm{M}$ only. When cells were treated with minocycline in concentrations between 50 and $150 \mu \mathrm{M}$ and then subsequently treated with $200 \mu \mathrm{M} \mathrm{H}_{2} \mathrm{O}_{2}$, a pronounced dose-dependent decrease in the viability of cells was detected (figure 1).

\section{Live-dead assay for corneal endothelial cells}

Minocycline concentrations between 1 and $75 \mu \mathrm{M}$ did not show any significant effect on cell viability in CECs, either after $24 \mathrm{~h}$ treatment or after additional treatment with $200 \mu \mathrm{M} \mathrm{H}_{2} \mathrm{O}_{2}$ for $4 \mathrm{~h}$. When CECs were treated with minocycline in a concentration of $20 \mu \mathrm{M}$, no increase of the percentage of non-viable cells could be detected $(p=1.0)$. In contrast, pre-treatment with $20 \mu \mathrm{M}$ minocycline did reduce the number of death cells when treated with $200 \mu \mathrm{M} \mathrm{H}_{2} \mathrm{O}_{2}$ for $4 \mathrm{~h}(\mathrm{p} \leq 0.001)$ compared with controls (figure 2). High concentrations of minocycline $(>75 \mu \mathrm{M})$ induced a marked, dose-dependent reduction of viable CECs (data not shown).

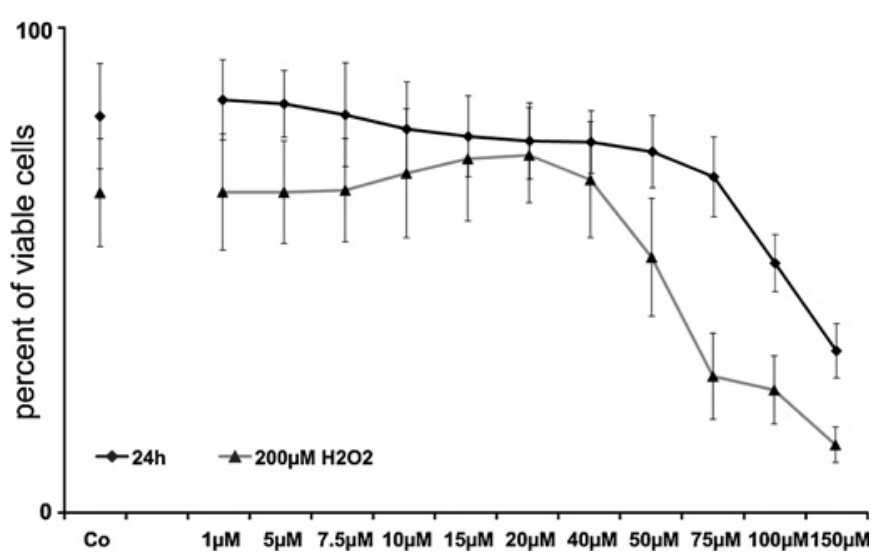

Figure 1 The viability of corneal endothelial cells (CECs) after 24-h treatment with the concentrations of minocycline investigated (black curve, diamonds) and additionally treated with $200 \mu \mathrm{M} \mathrm{H}_{2} \mathrm{O}_{2}$ (grey curve, triangles), measured by a colorimetric test (MTT). x-Axis: concentrations of minocycline tested. Error bars, SD. 
Figure 2 Corneal endothelial cells (CECs) were treated for $24 \mathrm{~h}$ with only or treated with minocycline for $24 \mathrm{~h}$ and $200 \mu \mathrm{M} \mathrm{H}_{2} \mathrm{O}_{2}$ for $4 \mathrm{~h}$ as described. After exposure of the cells to the substance alone or in combination with oxidative stress, viability was determined by staining all nuclei with Hoechst 33342 and dead cells with propidium iodide. (A) Representative fluorescence photomicrograph of Hoechst 33342-stained, untreated CECs as the control. (B) Non-viable cells in the corresponding field.

(C) Fluorescence photomicrograph of CECs treated with $20 \mu \mathrm{M}$ minocycline for $48 \mathrm{~h}$ and labelled with Hoechst 33342. (D) Non-viable CECs treated with $20 \mu \mathrm{M}$ for $48 \mathrm{~h}$ in the same field. (E) Fluorescence photomicrograph of CECs treated with $200 \mu \mathrm{M} \mathrm{H}_{2} \mathrm{O}_{2}$ only. (F) Non-viable CECs treated with $200 \mu \mathrm{M} \mathrm{H} \mathrm{O}_{2}$ only in the same field. (G) Fluorescence photomicrograph of CECs treated with minocycline concentrations of $20 \mu \mathrm{M}$ for $24 \mathrm{~h}$ and with $200 \mu \mathrm{M} \mathrm{H}_{2} \mathrm{O}_{2}$ and labelled with Hoechst 33342. (H) Non-viable CECs treated with minocycline

concentrations of $20 \mu \mathrm{M}$ for $48 \mathrm{~h}$ and with $200 \mu \mathrm{M} \mathrm{H}_{2} \mathrm{O}_{2}$ in the same field. (A-H) White scale bar: $100 \mu \mathrm{m}$. various concentrations of minocycline

Hoechst 33342

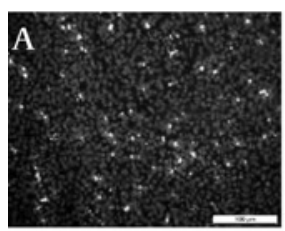

Control

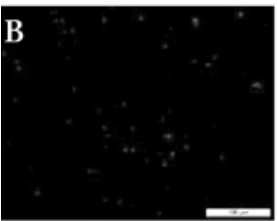

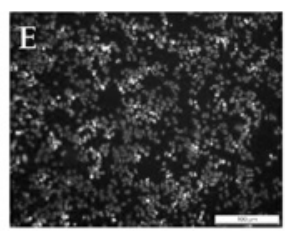

Control

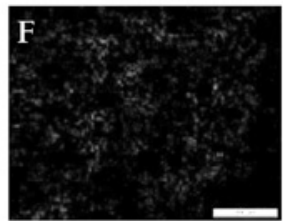

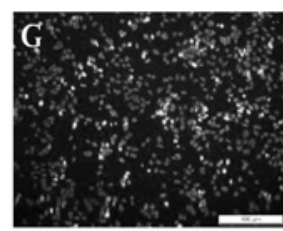

M $20 \mu \mathrm{M}$
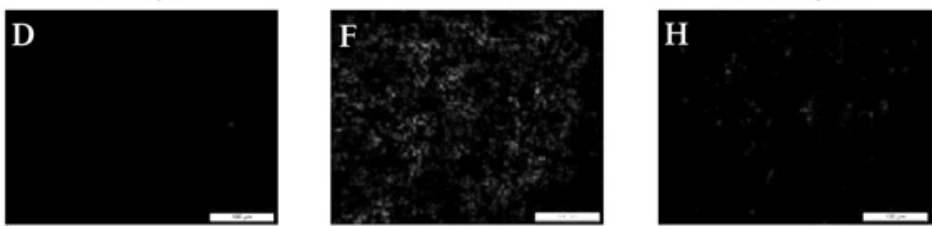

\section{propidium iodide}

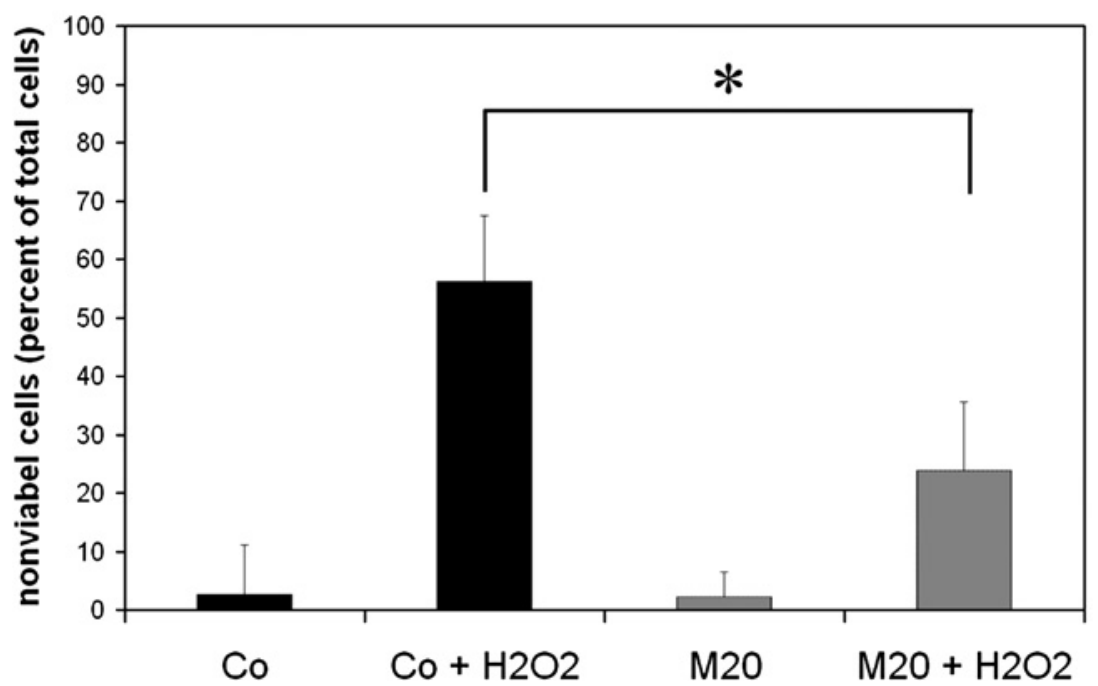

Figure 3 Inhibitory effect of minocycline on transforming growth factor beta (TGF- $\beta$ )2- and $\mathrm{H}_{2} \mathrm{O}_{2}$-induced apoptosis in corneal endothelial cells (CECs). Histone-associated DNA fragmentation in CECs as investigated by an ELISA method: untreated control (Co), CECs treated with $200 \mu \mathrm{M} \mathrm{H}_{2} \mathrm{O}_{2}$ $\left(\mathrm{H}_{2} \mathrm{O}_{2}\right)$ or TGF- $\beta 2$, after treatment with 15 and $20 \mu \mathrm{M}$ minocycline (M15 and M20) only, or after minocycline treatment and additional treatment with $200 \mu \mathrm{M} \mathrm{H}_{2} \mathrm{O}_{2}$ or TGF- $\beta 2$. Each value was normalised to the mean amount of histone-associated DNA fragments detected in the control. Data values are mean $\pm S D$. $y$-Axis: ratio of histone-associated DNA fragmentation of each probe normalised to histone-associated DNA fragmentation of the control. quantitative detection of histone-associated DNA fragmentation in CECs

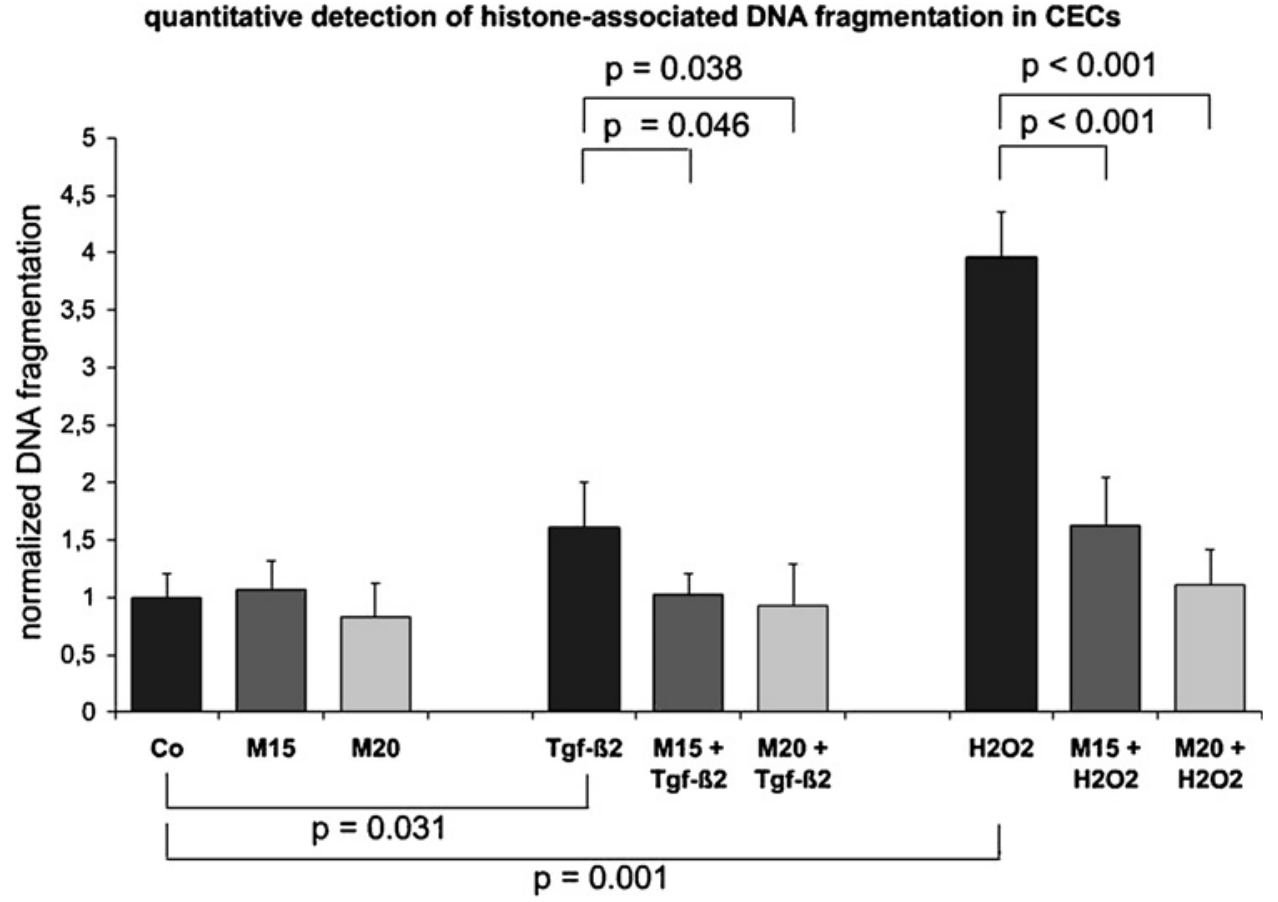




\section{Detection of apoptosis}

To investigate the effect of minocycline on apoptosis due to $200 \mu \mathrm{M} \mathrm{H} \mathrm{H}_{2} \mathrm{O}_{2}$ or TGF- $\beta 2$ exposure in CECs, a quantitative detection of histone-associated DNA fragments in monoand oligonucleosomes was conducted by using an ELISA method.

In our experimental set-up, both $200 \mu \mathrm{M} \mathrm{H}_{2} \mathrm{O}_{2}(\mathrm{p} \leq 0.001)$ and TGF- $\beta 2$ ( $p=0.031)$ led to a significant increase of histone-associated DNA fragments in cultured CECs. In contrast, when cells were pretreated with minocycline for $24 \mathrm{~h}$ and then exposed to $200 \mu \mathrm{M}$ $\mathrm{H}_{2} \mathrm{O}_{2}$ or TGF- $\beta 2$, minocycline treatment decreased the amount of histone-associated DNA fragments significantly compared with those cells that were treated with $\mathrm{H}_{2} \mathrm{O}_{2}$ or TGF- $\beta 2$ alone (figure 3 ).

\section{Expression of Bcl-2 and XIAP mRNA in CECs}

$\mathrm{Bcl}-2$ and XIAP mRNA expression was detected in every sample. All detected mRNA levels of Bcl-2 and XIAP were normalised to those of $18 \mathrm{~S}$ rRNA, and values are expressed as the relative ratio (RR) of
$\mathrm{Bcl}-2 / 18 \mathrm{~S}$ or XIAP/18S. The findings indicate that treatment with minocycline leads to an increased mRNA expression of both $\mathrm{Bcl}-2$ and XIAP. In contrast, TGF- $\beta 2$ and $\mathrm{H}_{2} \mathrm{O}_{2}$ treatment significantly decreased mRNA expression of Bcl-2 and XIAP in CECs.

The cells treated with both minocycline and with TGF- $\beta 2$ or $\mathrm{H}_{2} \mathrm{O}_{2}$ seemed to compensate for the decrease of Bcl-2 and XIAP mRNA expression by TGF- $\beta 2$ and $\mathrm{H}_{2} \mathrm{O}_{2}$ reaching mRNA levels of Bcl-2 and XIAP comparable to those of the untreated controls or even higher. In addition, the cells pre-treated with minocycline showed significantly higher levels of Bcl-2 and XIAP mRNA in CECs than cells treated with TGF- $\beta 2$ or $\mathrm{H}_{2} \mathrm{O}_{2}$ only (figure 4).

\section{Protein expression of Bcl-2 and XIAP in human CECs}

To verify that the decrease in Bcl-2 and XIAP under TGF- $\beta 2$ and $\mathrm{H}_{2} \mathrm{O}_{2}$ treatment and the minocycline-induced increase in $\mathrm{Bcl}-2$ and XIAP in mRNA transcription translates into increased protein synthesis, whole cellular protein extracts whole cellular
Figure 4 B-cell CLL/lymphoma 2 (Bcl-2) and X-linked inhibitor of apoptosis (XIAP) mRNA expression of corneal endothelial cells (CECs) after $24 \mathrm{~h}$ treatment with 15 or $20 \mu \mathrm{M}$ minocycline (M15 or M20) only or after additional treatment with $200 \mathrm{mM} \mathrm{H}_{2} \mathrm{O}_{2}$ or TGF- $\beta 2$, as investigated by quantitative RT-PCR. x-Axis: concentrations of minocycline tested; $\mathrm{y}$-axis: relative ratio (RR) of $\mathrm{Bcl}-2$ mRNA normalised to $18 \mathrm{~S}$ rRNA expressed in decimal format.
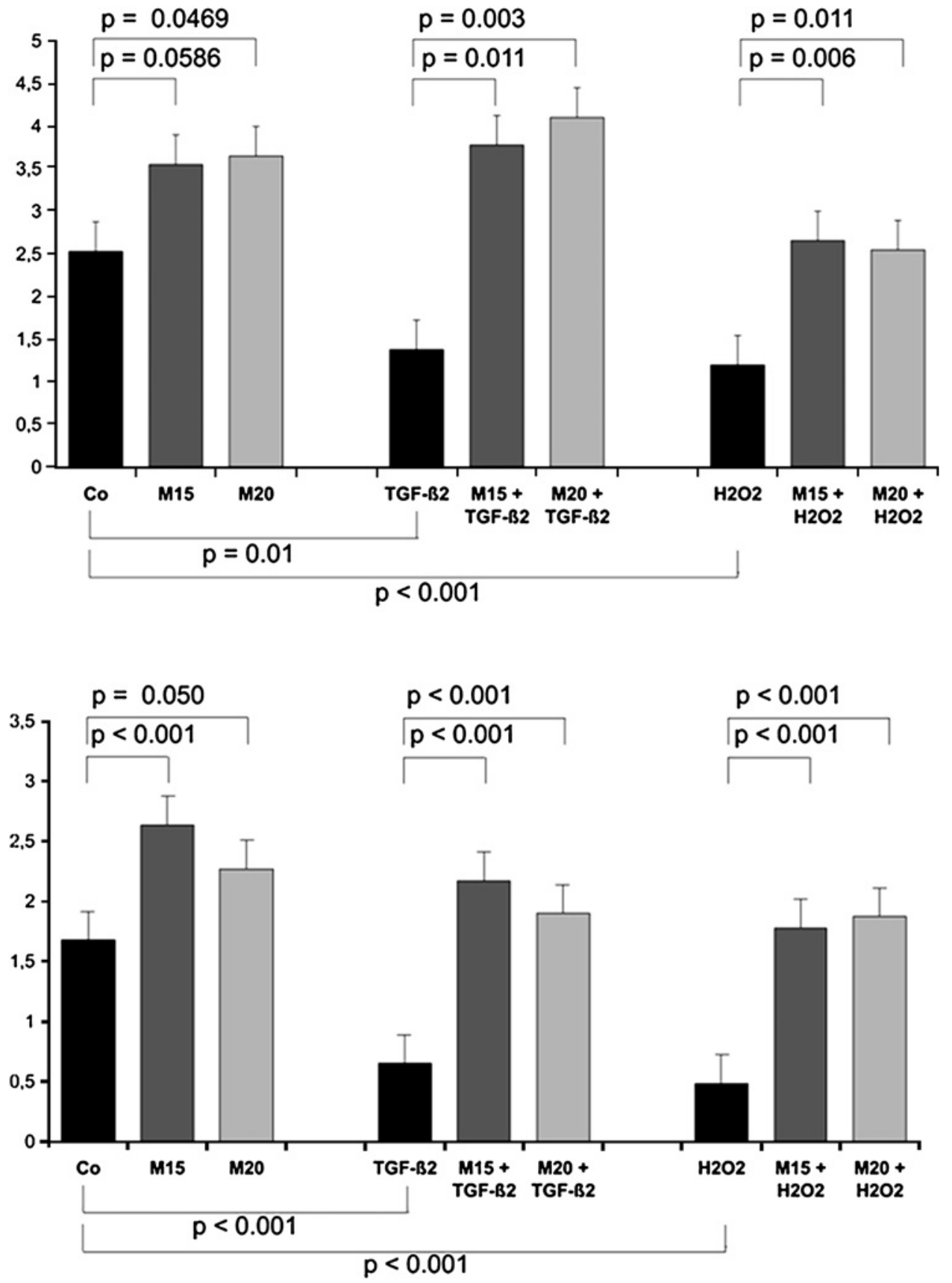
protein extracts of untreated CECs as the control, cells treated with minocycline concentrations alone, and cells consecutively treated with TGF- $\beta 2$ or $200 \mu \mathrm{M} \mathrm{H}_{2} \mathrm{O}_{2}$, were analysed by western blotting. An even protein load in each lane was confirmed by the staining of the polyvinyl difluoride membranes with Coomassie Brilliant Blue after the blotting procedure.

Both treatment with $200 \mu \mathrm{M} \mathrm{H}_{2} \mathrm{O}_{2}$ and TGF- $\beta 2$ treatment decreased Bcl-2 and XIAP expression in CECs compared with the control. CECs that were pre-treated with $20 \mu \mathrm{M}$ minocycline and then treated with $200 \mu \mathrm{M} \mathrm{H}_{2} \mathrm{O}_{2}$ showed a significantly lower decrease of both $\mathrm{Bcl}-2$ and XIAP expression compared with the control than those cells that were treated only with $\mathrm{H}_{2} \mathrm{O}_{2}$. The same effect was detected for TGF- $\beta 2$ treatment. CECs that were pre-treated with $20 \mu \mathrm{M}$ minocycline showed a significant increased expression of Bcl-2 and XIAP compared with the control (figure 5).

\section{DISCUSSION}

Deterioration of the corneal endothelium can lead to endothelial cell loss and irreversible opacification of the cornea. Such loss is serious in humans as the capacity of corneal endothelial cell regeneration is limited. ${ }^{2} 3$ Therefore, one major prerequisite for corneal clarity is the endothelial cell count.

Apoptosis is an important mechanism of corneal endothelial cell loss, both in physiological and pathological conditions. ${ }^{10}$ In vitro investigations of bovine corneal endothelial cells have demonstrated that endothelial cell apoptosis is mediated by oxidative stress and that apoptosis is dependent on local environmental factors. ${ }^{27} 28$ The aim of our study was to elucidate whether the tetracycline antibiotic minocycline offers properties to prevent apoptotic cell death and consecutive CEC loss in a cultured human corneal endothelial cell line in vitro. The cell line investigated does not only offer the morphological characteristics of the physiological corneal endothelium in vivo, but

\section{Protein Expression in CECs}

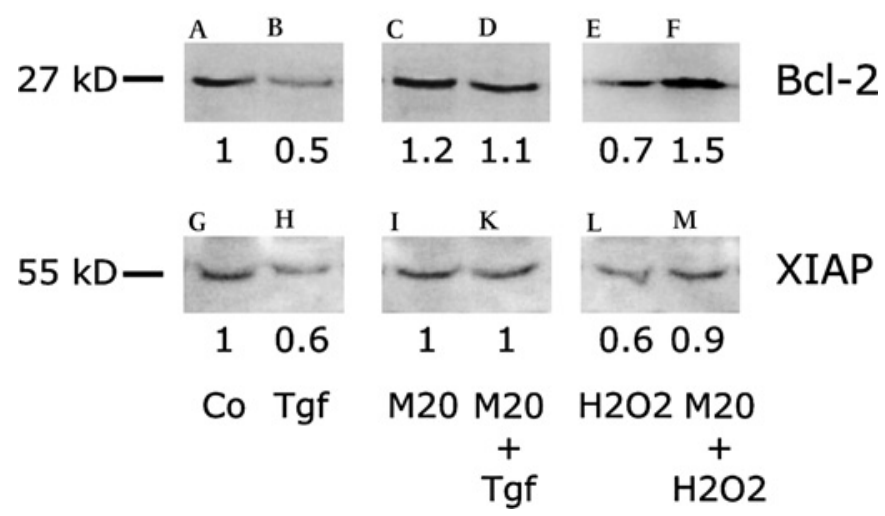

Figure 5 Effects of minocycline-treatment on B-cell CLL/lymphoma 2 (Bcl-2) and X-linked inhibitor of apoptosis (XIAP) protein expression. Corneal endothelial cells (CECs) were treated with $20 \mu \mathrm{M}$ Minocycline for $24 \mathrm{~h}$ only or additionally with TGF- $\beta 2(1 \mathrm{ng} / \mathrm{ml})$ or $200 \mu \mathrm{M} \mathrm{H} \mathrm{H}_{2}$. Western blotting was used to analyse protein expression in the control ( $A$ and $G$ ) and in treated cell extracts: TGF- $\beta 2$ (B and $H), 20 \mu \mathrm{M}$ minocycline ( $\mathrm{C}$ and $\mathrm{I}), 20 \mu \mathrm{M}$ minocycline and TGF- $\beta 2$ (D and $\mathrm{K}$ ), $200 \mu \mathrm{M} \mathrm{H} \mathrm{O}_{2}$ (E and $\mathrm{L}$ ), and $20 \mu \mathrm{M}$ minocycline and $200 \mu \mathrm{M} \mathrm{H} \mathrm{O}_{2}$ (F and M). Protein expression in control cell extracts was set as ' 1 '. The values indicate the ratios of treated cell extracts compared with control cell extracts. Ten micrograms of protein were loaded per lane. Even protein load in each lane was confirmed by Coomassie Brilliant Blue staining of the polyvinyl difluoride membranes. also possesses functional properties, such as the capacity to regulate stromal hydration. ${ }^{29}$ The data presented might be useful in the prevention of endothelial cell loss of cultured donor corneas for transplantation and under certain conditions in vivo.

Minocycline is a well established and safe drug and has proven its antimicrobial and anti-inflammatory qualities for many years. ${ }^{19}$ In addition to its antibiotic and anti-inflammatory activity, it has been shown to have cytoprotective characteristics against various stimuli, including oxidative stress, ischaemia and cytokines. $^{22}$ 30-32 The cytoprotective effects of minocycline have been suggested to be anti-inflammatory and also antiapoptotic. Recent reports have demonstrated minocycline's antioxidant properties and its influence on caspases and nitric oxide synthase activity. ${ }^{33}$ Its inhibiting effect on the release of apoptotic proteins, such as cytochrome $c$ and Smac/Diabolo, and its induction of anti-apoptotic proteins, such as Bcl-2 or XIAP, have been described in several cellular systems. ${ }^{20} 22$

Our results demonstrate that minocycline protects cultured corneal endothelial cells from oxidative stress. We were able to show that oxidative stress due to $\mathrm{H}_{2} \mathrm{O}_{2}$ leads to an increase of cell death and apoptosis in the investigated human CEC line. This induction of apoptotic cell death went along with a decrease of two anti-apoptotic proteins-Bcl-2 and XIAP. In contrast, we were able to show that minocycline is able to attenuate this induction of cell death and that at least one cytoprotective mechanism of minocycline is its induction of these anti-apoptotic proteins (Bcl-2 and XIAP).

$\mathrm{Bcl}-2$ is generally considered to be a custodian of mitochondrial functional integrity as it stabilises the mitochondrial membrane against the release of cytochrome $c$. Through its inhibitory effect on caspase activation, Bcl-2 is able to interrupt apoptosis. ${ }^{34}$ It has been shown that Bcl-2 mediates cell survival and decreases apoptosis in human retinal pigment epithelial cells $(\mathrm{RPE})^{35}$ and other ocular and non-ocular cell lines. ${ }^{36}{ }^{37}$ XIAP is another potent and well-characterised anti-apoptotic protein. It is related to the tumour suppressor protein p35, which suppresses the activity of the apoptosis-promoting key caspases 3, 7 and $9 .{ }^{38}$ It has been demonstrated that the overexpression of XIAP protects injured neuronal cells and photoreceptors from further compromise in vivo. ${ }^{39} 40$

The growth factor TGF- $\beta$ is expressed by almost every cell. Altered levels of TGF- $\beta$ are associated with several ocular pathologies, including glaucoma. ${ }^{14}$ It has been demonstrated that both acute and chronic glaucoma can lead to endothelial cell loss and that preoperative glaucoma is a major risk factor for increased endothelial cell loss following keratoplasty. ${ }^{41} 42$ So another important finding of our investigations is that TGF- $\beta 2$, the isoform of TGF- $\beta$ most expressed in human eyes, induced apoptotic cell death in human CECs. This corresponds well to the apoptotic effects of TGF- $\beta$ described previously in many cellular systems. ${ }^{14}$ This induction of apoptosis was accompanied by a reduction of Bcl-2 and XIAP levels in CECs. In contrast, we were able to show that minocycline increases Bcl-2 and XIAP expression on both the RNA level and the protein level, not only under standard conditions but also under conditions of oxidative stress and increased levels of TGF- $\beta 2$.

Because of its antibiotic and anti-inflammatory actions, minocycline is widely used and has proven its safety as an oral antibiotic for many years. ${ }^{19} 43$ In our in vitro study, treatment of CEC with minocycline in concentrations up to $50 \mu \mathrm{M}$ under standard conditions did not reveal significant toxicity. However, after treatment with $\mathrm{H}_{2} \mathrm{O}_{2}$, doses $>40 \mu \mathrm{M}$ led to a significant decrease in the viability of cells. In our experimental setting minocycline concentrations of $20 \mu \mathrm{M}$ revealed anti-apoptotic 
effects. This would correspond to an estimated dose of approximately $750 \mathrm{mg} /$ day in human adults, which is undoubtedly a high dosage. ${ }^{19} 4445$ On the other hand, previous reports have shown that daily tetracyclin doses $>2000 \mathrm{mg}$ are still relatively safe in healthy pregnant women ${ }^{19}$ Our results from cell culture experiments seem to indicate that minocycline protects the corneal endothelium from two potential apoptotic stimuli. In addition, minocycline increases the expression of two anti-apoptotic proteins in cultured CECs. Even if the therapeutic range of minocycline in our setting was limited, it might be worthwhile to further investigate minocycline's anti-apoptotic and cyto-protective effects on the corneal endothelium.

The CECs we used for our experiments have demonstrated morphological characteristics of the physiological corneal endothelium in vivo, but also possess functional properties, such as the capacity to regulate stromal hydration. ${ }^{29}$ Nevertheless, one major limitation of our study might be that the cells we used for our experiments were from an immortalised, cultured cell line with all its limitations, and our results cannot be directly transferred in vivo. In addition, it is not clear that the cytoprotective effect of minocycline seen after short-term exposure also occurs after long-term exposure.

Nevertheless, our findings indicate that minocycline might offer cytoprotective properties that could help to increase corneal endothelial cell survival and resistance to stress as it occurs under certain pathological conditions and ocular disease. 9 The antiapoptotic, cytoprotective effects of minocycline described here may provide a basis for the prevention of corneal endothelial cell loss under pathological conditions and help to make these cells less susceptible to cellular stress. Indeed, further investigations are necessary to corroborate this data, but our in vitro findings suggest that minocycline might offer properties that could potentially prevent corneal endothelial cell loss in vivo.

Acknowledgements The authors thank Professor $\mathrm{J}$ Bednarz for providing cultured corneal endothelial cells. We also thank Professor U Welge-Lussen for providing laboratory equipment and Katja Obholzer for excellent technical assistance.

Competing interests None.

Provenance and peer review Not commissioned; externally peer reviewed.

\section{REFERENCES}

1. Bourne WM, Kaufman HE. The endothelium of clear corneal transplants. Arch Ophthalmol 1976;94:1730-2.

2. Kaufman HE, Katz Jl. Pathology of the corneal endothelium. Invest Ophthalmol Vis Sci 1977; 16:265-8.

3. Van Horn DL, Hyndiuk RA. Endothelial wound repair in primate cornea. Exp Eye Res 1975;21:113-24.

4. Yee RW, Matsuda M, Schultz R0, et al. Changes in the normal corneal endothelial cellular pattern as a function of age. Curr Eye Res 1985;4:671-8.

5. Bourne WM. One-year observation of transplanted human corneal endothelium. Ophthalmology 1980;87:673-9.

6. Armitage WJ, Easty DL. Factors influencing the suitability of organ-cultured corneas for transplantation. Invest Ophthalmol Vis Sci 1997;38:16-24.

7. Borderie VM, Scheer S, Touzeau 0, et al. Donor organ cultured corneal tissue selection before penetrating keratoplasty. Br J Ophthalmol 1998;82:382-8.

8. Temple MD, Perrone GG, Dawes IW. Complex cellular responses to reactive oxygen species. Trends Cell Biol 2005;15:319-26.

9. Lux-Neuwirth 0, Millar TJ. Lipid soluble antioxidants preserve rabbit corneal cell function. Curr Eye Res 1990;9:103-9.

10. George AJ, Larkin DF. Corneal transplantation: the forgotten graft. Am J Transplant 2004:4:678-85.

11. Ochiai $\mathbf{Y}$, Ochiai $\mathrm{H}$. Higher concentration of transforming growth factor-beta in aqueous humor of glaucomatous eyes and diabetic eyes. Jpn J Ophthalmol 2002:46:249-53.

12. Shi Y, Massague J. Mechanisms of TGF-beta signaling from cell membrane to the nucleus. Cell 2003;113:685-700.

13. Rocha G, Baines MG, Deschenes J, et al. Nitric oxide and transforming growth factor-beta levels during experimental uveitis in the rabbit. Can J Ophthalmol 1997;32:17-24
14. Massague J. The transforming growth factor-beta family. Annu Rev Cell Biol 1990;6:597-641.

15. Huang SS, Huang JS. TGF-beta control of cell proliferation. J Cell Biochem 2005:96:447-62

16. Yao K, Tan J, Gu WZ, et al. Reactive oxygen species mediates the apoptosis induced by transforming growth factor beta(2) in human lens epithelial cells. Biochem Biophys Res Commun 2007;354:278-83.

17. Chen KH, Harris DL, Joyce NC. TGF-beta2 in aqueous humor suppresses S-phase entry in cultured corneal endothelial cells. Invest Ophthalmol Vis Sci 1999;40:2513-19.

18. Chen KH, Hsu WM, Chiang CC, et al. Transforming growth factor-beta2 inhibition of corneal endothelial proliferation mediated by prostaglandin. Curr Eye Res 2003;26:363-70

19. Klein NC, Cunha BA. Tetracyclines. Med Clin North Am 1995;79:789-801.

20. Chen M, Ona VO, Li M, et al. Minocycline inhibits caspase-1 and caspase-3 expression and delays mortality in a transgenic mouse model of Huntington disease. Nat Med 2000:6:797-801.

21. Sanchez Mejia Ro, Ona VO, Li M, et al. Minocycline reduces traumatic brain injury-mediated caspase-1 activation, tissue damage, and neurological dysfunction. Neurosurgery 2001;48:1393-9; discussion 99-401.

22. Wang J, Wei $\mathrm{Q}$, Wang $\mathrm{CY}$, et al. Minocycline up-regulates $\mathrm{Bcl}-2$ and protects against cell death in mitochondria. J Biol Chem 2004;279:19948-54.

23. Bosco A, Inman DM, Steele MR, et al. Reduced retina microglial activation and improved optic nerve integrity with minocycline treatment in the DBA/2J mouse model of glaucoma. Invest Ophthalmol Vis Sci 2008;49:1437-46.

24. Bednarz J, Teifel $M$, Friedl $P$, et al. Immortalization of human corneal endothelial cells using electroporation protocol optimized for human corneal endothelial and human retinal pigment epithelial cells. Acta Ophthalmol Scand 2000;78:130-6.

25. Mosmann T. Rapid colorimetric assay for cellular growth and survival: application to proliferation and cytotoxicity assays. J Immunol Methods 1983;65:55-63.

26. Kernt M, Neubauer AS, Liegl R, et al. Cytoprotective effects of a blue light-filtering intraocular lens on human retinal pigment epithelium by reducing phototoxic effects on vascular endothelial growth factor-alpha, Bax, and Bcl-2 expression. J Cataract Refract Surg 2009;35:354-62.

27. Cho KS, Lee EH, Choi JS, et al. Reactive oxygen species-induced apoptosis and necrosis in bovine corneal endothelial cells. Invest Ophthalmol Vis Sci 1999:40:911-19.

28. Thompson CB. Apoptosis in the pathogenesis and treatment of disease. Science 1995:267:1456-62.

29. Mergler S, Dannowski H, Bednarz J, et al. Calcium influx induced by activation of receptor tyrosine kinases in SV40-transfected human corneal endothelial cells. Exp Eye Res 2003;77:485-95.

30. Lee SM, Yune TY, Kim SJ, et al. Minocycline inhibits apoptotic cell death via attenuation of TNF-alpha expression following iNOS/NO induction by lipopolysaccharide in neuron/glia co-cultures. J Neurochem 2004;91:568-78.

31. Wang AL, Yu AC, Lau LT, et al. Minocycline inhibits LPS-induced retinal microglia activation. Neurochem Int 2005;47:152-8.

32. Zanjani TM, Sabetkasaei M, Mosaffa N, et al. Suppression of interleukin-6 by minocycline in a rat model of neuropathic pain. Eur J Pharmacol 2006;538:66-72.

33. Kraus RL, Pasieczny R, Lariosa-Willingham $\mathrm{K}$, et al. Antioxidant properties of minocycline: neuroprotection in an oxidative stress assay and direct radicalscavenging activity. J Neurochem 2005;94:819-27.

34. Esposti MD, Hatzinisiriou I, McLennan $\mathrm{H}$, et al. Bcl-2 and mitochondrial oxygen radicals. New approaches with reactive oxygen species-sensitive probes. $J$ Biol Chem 1999;274:29831-7.

35. Godley BF, Jin GF, Guo YS, et al. Bcl-2 overexpression increases survival in human retinal pigment epithelial cells exposed to $\mathrm{H}(2) 0(2)$. Exp Eye Res 2002;74:663-9.

36. Chen J, Flannery JG, LaVail MM, et al. bcl-2 overexpression reduces apoptotic photoreceptor cell death in three different retinal degenerations. Proc Natl Acad Sci U S A 1996;93:7042-7

37. Ryan JJ, Prochownik E, Gottlieb CA, et al. c-myc and bcl-2 modulate p53 function by altering p53 subcellular trafficking during the cell cycle. Proc Natl Acad Sci U S A 1994:91:5878-82.

38. Clem RJ. Baculoviruses and apoptosis: the good, the bad, and the ugly. Cell Death Differ 2001;8:137-43

39. McKinnon SJ, Lehman DM, Tahzib NG, et al. Baculoviral IAP repeat-containing-4 protects optic nerve axons in a rat glaucoma model. Mol Ther 2002:5:780-7.

40. Petrin D, Baker A, Coupland SG, et al. Structural and functional protection of photoreceptors from MNU-induced retinal degeneration by the X-linked inhibitor of apoptosis. Invest Ophthalmol Vis Sci 2003;44:2757-63.

41. Olsen T. The endothelial cell damage in acute glaucoma. On the corneal thickness response to intraocular pressure. Acta Ophthalmol (Copenh) 1980;58:257-66.

42. Sihota R, Lakshmaiah NC, Titiyal JS, et al. Corneal endothelial status in the subtypes of primary angle closure glaucoma. Clin Experiment Ophthalmol 2003;31:492-5.

43. Ryan ME, Greenwald RA, Golub LM. Potential of tetracyclines to modify cartilage breakdown in osteoarthritis. Curr Opin Rheumatol 1996;8:238-47.

44. Goulden V, Glass D, Cunliffe WJ. Safety of long-term high-dose minocycline in the treatment of acne. Br J Dermatol 1996;134:693-5.

45. Hartwig H, Mester U, Krasemann C. [Concentration of minocycline in human aqueous humor after oral administration (author's transl)]. Klin Monatsbl Augenheilkd 1978;173:842-5 


\section{Minocycline is cytoprotective in human corneal endothelial cells and induces anti-apoptotic B-cell CLL/lymphoma 2 (Bcl-2) and X-linked inhibitor of apoptosis (XIAP)}

Marcus Kernt, C Hirneiss, A S Neubauer, et al.

Br J Ophthalmol 2010 94: 940-946

doi: 10.1136/bjo.2009.165092

Updated information and services can be found at:

http://bjo.bmj.com/content/94/7/940.full.html

\section{These include:}

References This article cites 45 articles, 12 of which can be accessed free at: http://bjo.bmj.com/content/94/7/940.full.html\#ref-list-1

Article cited in:

http://bjo.bmj.com/content/94/7/940.full.html\#related-urls

Email alerting Receive free email alerts when new articles cite this article. Sign up in service the box at the top right corner of the online article.

Topic Articles on similar topics can be found in the following collections Collections

Notes

To request permissions go to:

http://group.bmj.com/group/rights-licensing/permissions

To order reprints go to:

http://journals.bmj.com/cgi/reprintform

To subscribe to BMJ go to:

http://group.bmj.com/subscribe/ 